Published in Organization Studies. Please cite as:

Jarzabkowski, P. \& J. A. A. Sillince 2007. 'A rhetoric-in-context approach to shaping commitment to multiple strategic goals'. Organization Studies,

28.10: 1639-65.

\title{
A RHETORIC-IN-CONTEXT APPROACH TO BUILDING COMMITMENT TO MULTIPLE STRATEGIC GOALS ${ }^{1}$
}

\author{
Authors \\ Paula Jarzabkowski \\ Aston Business School \\ Aston University \\ Birmingham, UK, B4 7ET \\ P.A.Jarzabkowski@aston.ac.uk \\ Phone: +44 (0)121 2043139 \\ John A.A. Sillince \\ Aston Business School, \\ Aston University, \\ Birmingham, UK, B4 7ET \\ j.a.a.sillince@aston.ac.uk \\ Phone +44 (0)1212043239
}

\footnotetext{
${ }^{1}$ The authors would like to thank the editor, Cynthia Hardy, and the three anonymous reviewers for their help with developing this paper, as well as Andrew Brown, Loizos Heracleous and Mike Wallace for their helpful comments on drafts of the paper.
} 


\title{
A RHETORIC-IN-CONTEXT APPROACH TO BUILDING COMMITMENT TO MULTIPLE STRATEGIC GOALS
}

\begin{abstract}
There are still few explanations of the micro level practices by which top managers influence employee commitment to multiple strategic goals. This paper argues that through their language, top managers can construct a context for commitment to multiple strategic goals. We therefore propose a rhetoric-in-context approach to illuminate some of the micro practices through which top managers influence employee commitment. Based upon an empirical study of the rhetorical practices through which top managers influence academic commitment to multiple strategic goals in university contexts, we demonstrate relationships between rhetoric and context. Specifically, we show that rhetorical influences over commitment to multiple goals are associated with the historical context for multiple goals, the degree to which top managers' rhetoric instantiates a change in that context, and the internal consistency of the rhetorical practices used by top managers.
\end{abstract}

Keywords: commitment; rhetoric; multiple strategic goals; universities; context 
Jarzabkowski, P. \& J. A. A. Sillince 2007. 'A rhetoric-in-context approach to shaping commitment to multiple strategic goals'. Organization Studies, 28.10: 1639-65.

Little is known about the specific resources that top managers use to generate commitment from organization members or their effects and limitations in different contexts. This paper addresses this gap through an empirical study of the rhetorical practices that top managers use to influence academic commitment to multiple strategic goals in three universities. The findings make three contributions. First, they illustrate how rhetoric can influence commitment to multiple goals. Second, they contribute to grounding rhetoric theory within context by showing how rhetoric varies across contexts. Third they elaborate the importance of internal consistency within rhetorical practices.

\section{THEORETICAL BACKGROUND}

As commitment is an internally experienced sense of duty toward, ownership over or identification with a task, much of the literature has defined commitment as individual willingness to cooperate in a task (e.g. Korsgaard, Schweiger, and Sapienza, 1995; Pierce, Kostova \& Dirks, 2001),. However, organizational attempts to generate commitment are directed at groups or units, focusing upon collective commitment by organizational members rather than commitment by isolated individuals. Increasingly, therefore, commitment is examined as a collective construct. For example, studies examine how employee participation in strategic planning socializes employees into identification with and collective commitment to strategic goals (Schaffer and Willauer, 2003), which they perceive that they can influence (Kosgaard, Schweiger and Sapienza, 1995). When multiple members of an organization experience a sense of ownership over decisions that affect them, they generate social norms of identification with those decisions that reinforces the collective sense of commitment (Constant, Sproull and Kiesler, 1996). This paper adopts this collective view of commitment, as willingness to cooperate in a task by organizational members at large.

While commitment has socialized elements of ownership and identification, it also has calculative dimensions (Siders, George \& Dharwadkar, 2001). The calculative dimension emphasizes that commitment involves balancing obligations and rewards (Mackin, 1996). For example, organizational members may not believe in a particular goal and yet can be persuaded that it meets their self-interest to cooperate. Fligstein (1997) argued that strategic actors convince others that what will occur is either in line with widely-accepted socialized logics of action or in their narrow self interest. Commitment to organizational goals may be more a matter of pragmatic choice 
Jarzabkowski, P. \& J. A. A. Sillince 2007. 'A rhetoric-in-context approach to shaping commitment to multiple strategic goals'. Organization Studies, 28.10: 1639-65.

than is evident in theories of socialized commitment. Members have keen awareness of their own strategic self-interest, which may be different from that of top managers. Collective commitment is therefore given as an obligation to enact an organizational goal in return for organizational support, which may later lead to individual benefits in terms of compensation, promotion, recognition or other rewards. This implies a relationship guided by reciprocity (Blau, 2002), relational exchanges (Floyd and Lane, 2000) or patronage (Jackall, 1988). Such calculative dimensions of commitment may become normative when they are manifested as an enduring obligation rather than an expectation of immediate gratification. Therefore, an important factor in top managers' ability to influence commitment to strategic goals is whether employees perceive that commitment will be reciprocated with outcomes that meet their self interest.

While the existing literature emphasizes commitment to the organization as a whole, it does not explain how top managers influence commitment to multiple strategic goals. Existing theory does not explain the micro variations in influence needed to widen members' existing spheres of commitment to include additional goals or to shift their commitment from one goal towards another. For example, the literature on organizational identification explains the process of changing commitment as first detaching the individual from the organization (dis-identification) and then re-attaching him/her to a changed organization (re-identification) (e.g. Chreim, 2002; Fiol, 2002; Reger et al. 1994). This approach is insufficiently fine-grained for examining commitment to multiple goals, because it involves detachment and re-attachment of the individual to the whole organization, in which one set of goals is replaced by another set. By contrast, in the case of commitment to multiple strategic goals, top managers must emphasize different goals at different times and persuade organizational members that each of these goals is within their interests, requiring variations in influence that are as yet under-explained (Jarzabkowski, 2005).

In situations of multiple and ambiguous goals, top managers negotiate commitment with their workforce using methods that are "symbolic, intangible, and communicated verbally rather than through a written document. Language that is imprecise but value-laden allows individuals to feel their interests match those stated for the organization" (Middleton-Stone and Brush, 1996: 647). This indicates a fine-grained approach to managerial practice, going deeper than the level of the organization as a whole (Jarzabkowski et al, 2007). Through their language, top managers may 
Jarzabkowski, P. \& J. A. A. Sillince 2007. 'A rhetoric-in-context approach to shaping commitment to multiple strategic goals'. Organization Studies, 28.10: 1639-65.

emphasize some goals in some situations and emphasize others in different situations, encouraging organizational members to widen their sphere of commitment to embrace multiple goals. We therefore propose that rhetorical analysis can illuminate some of the micro practices through which top managers influence employee commitment to multiple strategic goals.

\section{Rhetoric and context}

This paper focuses upon rhetoric as it is used intra-organizationally by members in their interactions within organizations (e.g. Heracleous and Barrett, 2001; Mueller et al., 2004; Oswick et al., 2004; Symon, 2005; Sillince et al., 2001; Sillince, 2002). Commitment to organizational goals may be effected through rhetoric, which is defined as "the conscious, deliberate and efficient use of persuasion to bring about attitudinal or behavioural change" (Cheney et al., 2004: 84). Rhetoric is particularly indicated in the context of goal ambiguity because of its persuasive role in the absence of credible source, clear evidence, certain backing or logical support (Cheney et al., 2004). As universities have multiple goals that may involve divergent interests between top managers and their academic workforce, strategy involves contested interpretations which have ambiguous and socially constructed meanings. Rhetoric helps to achieve closure of meanings by plausibly positioning some interpretations as taken for granted or by excluding alternative constructions (Linstead, 2001). Strategy rhetoric projects purpose and is thus particularly powerful in bringing about closure of interpretations and generating organizational action (Hardy et al, 2000; Lilley, 2001).

As the meaning of all discourse (of which rhetoric is a persuasion-oriented part) is situated (Heracleous, 2002; Heracleous and Marshak, 2004), discourse gains meaning within the context of its use. Indexicality is the feature of language in which "meaning alters with the context of use" (Potter \& Wetherell, 1987: 23). For example, speech act theory (Austin, 1962; Searle, 1975) developed detailed rules about the meaning of utterances dependent on particular contexts. However, speech acts apply only at the level of talk-as-interaction and cannot be used to understand the way in which 'grand' discourses (Alvesson and Karreman, 2000) provide context. Similarly, conversation analysis is often criticised for its lack of engagement with broader issues and outcomes (Iedema, 2003). 'Language-in-use' studies are commonly criticized for focusing on the detailed aspects of discursive interaction to the neglect of relevant aspects of context (Grant et al., 2004; 
Jarzabkowski, P. \& J. A. A. Sillince 2007. 'A rhetoric-in-context approach to shaping commitment to multiple strategic goals'. Organization Studies, 28.10: 1639-65.

Heracleous, 2004; Iedema, 2003). However, some recent work on organizational discourse and rhetoric has suggested that studying language-in-use need not exclude context. As Hardy et al (2000: 1228) note 'Strategic actors cannot simply produce a discourse to suit their immediate needs and, instead, must locate their discursive activities within a meaningful context if they are to shape and construct action'. They argue that actors must construct explanations which make sense to others, and must embed their statements in common elements of context that provide a shared social order.

Classical rhetoric has a rich theory of context (Aristotle, 2000). For example, the speaker's ability to create a sense of 'presence' - that is here-and-now rooted-ness in a believable context adds to the speaker's effectiveness. Speech must have kairos by being relevant to the current contingency. There must be an alignment of the audience's previous emotional state and the emotion or pathos evoked by the speaker. When the audience is not in a high state of emotion, the speaker must speak logically. The extent of rhetors' effectiveness lies in their use of the commonplace contextualized assumptions of the audience.

Modern rhetoric scholars add to this notion of context and audience. For example, each new context has an imperative which evokes the speaker's rhetorical response (Bitzer, 1999), yet at the same time that imperative can be constructed by the speaker (Vatz, 1999). To be persuasive, speakers must demonstrate that they identify with the audience (Burke, 1969), anticipating and encompassing the audience's position and opinions (Bakhtin, 1981). The speaker and the audience thus collaboratively construct shifting perceptions of context according to shifting contingencies (Biesecker, 1999). For example, different speakers may draw upon context to construct different versions of the organizational past (Symon, 2005). The ability of speakers to draw upon and adapt to contextual contingencies is, therefore, indicative of the effectiveness of their rhetoric (White, 1992). The localized instantiation of context in interaction with the audience at a moment in time is, inherently, also a multi-level concept (Fairclough, 2001) because rhetorical effect is grounded within and draws upon the long-duration, shared context in which such interactions take place (Giddens, 1984; Heracleous, 2004)

We define the context in which rhetoric occurs, the 'rhetorical situation', as comprising first, urgency or an imperative to act, second, an audience whom the rhetor addresses, and third, the 
Jarzabkowski, P. \& J. A. A. Sillince 2007. 'A rhetoric-in-context approach to shaping commitment to multiple strategic goals'. Organization Studies, 28.10: 1639-65.

wider context of history, power and time, which affect the rhetor but can also be brought to bear on the identity and values of the audience (Bitzer, 1968). We follow Biesecker (1999) in arguing that context is negotiated between the rhetor and audience in a process that reflects their relative power.

This paper analyses rhetoric in context from the viewpoint of top managers shaping commitment to multiple strategic goals. Shaping commitment to multiple strategic goals elicits the relationship between rhetoric and context, as different goals will need to be framed as equally favourable to context, potentially requiring different aspects of context to be emphasized at different times (Heracleous, 2006). Strategy commitment provides an important link between rhetoric and context because it is contingent on interactions in a particular place and time and yet, equally, strategizing is embedded in the history of the organization and its attempts to project the future. Rhetorics involved in shaping commitment to strategy are specific to the context of interaction but are also involved in constructing a future strategic context. Context is instantiated through the discursive interaction of actors but has longer duration than any specific interaction. Thus, top managers may draw on context as a source of rhetorical influence but context also influences the way that top managers construct their agency. This is essential to our view of the relationship between rhetoric and context; rhetoric positions the self in relation to context, as well as positioning the context to an audience.

Drawing on this theoretical framing, we propose three research questions that guide the empirical study:

1. How do university top managers construct themselves rhetorically in relation to their academic community?

2. How do university top managers rhetorically position commitment to multiple strategic goals to the academic audience?

3. How does university top managers' rhetoric construct a context for academic commitment to multiple strategic goals?

These three empirical questions are drawn together under an overarching conceptual question: How does top managers' rhetoric vary in different contexts and what implications does this variation have for the rhetorical construction of commitment to multiple strategic goals? 
A case method was adopted in three UK universities (Eisenhardt, 1989). Drawing upon existing typologies (O’Leary, 1997), cases were selected from three types in order to reflect the broad parameters of approaches within the university sector to the multiple goals of research, teaching and commercial income (Slaughter and Leslie, 1999). Three cases that were within a realistic travel distance for rich qualitative data collection were selected on the basis that they met the typology criteria, offered equally high quality access to rich data, and were well ranked examples of their type. Collegiate was a turn of the $20^{\text {th }}$ century institution developed for the purpose of furthering the sciences and, therefore, strongly research oriented. It was predominantly concerned with excellent research but also had internationally recognized teaching programs and was developing a commercial strategy. Entrepreneurial, developed in the 1960s to cater to the government agenda of widening higher education, had an orientation towards both teaching and research but also had a strong reputation for its commercial strategy. Modern was a new university developed from a former polytechnic. It had a reputation for excellent and innovative teaching and was attempting to strengthen its commercial and research strategies.

A triangulated qualitative data set, including interviews, non-participant observation, and documentary searches (Eisenhardt, 1989) was gathered in three UK universities for a seven-year period (see Appendix A). Six years from 1992 to 1997 inclusive were retrospective collection and one year, 1998, was real-time.

A total of 49 open-ended interviews were held with all current top managers and, where pertinent to specific strategic actions studied, some former top managers and other managers (see Appendix B). Interviews probed both retrospective and current actions and lasted, typically, 90 minutes, of which 44 were audio-taped, the remaining five being reconstructed within 24 hours from detailed notes.

Serial non-participant observations of 51 strategic level meetings across the cases, averaging two hours per meeting, were conducted throughout the year of real-time data collection. Background that enhanced the interpretation of observations was accessible through committee minutes, interviews, and informal discussion with participants. Other non-participant observational data, such as pre- and post-meeting observations and other general on-site interactions, were collected to achieve greater familiarity with locally meaningful practices (Van Maanen, 1979). 
Additionally, Deputy Vice-Chancellors at Modern and at Entrepreneurial Universities were each shadowed for one week and at Collegiate the investigator spent whole day visits in the senior management wing at a desk next to the communal coffee machine frequented by all senior management and their support staff.

Minute books from key strategic committees for the period 1992 to 1997 inclusive were the principal source of documentary data. These were supported by documents such as annual reports, annual accounts, academic databases, strategic plans, audit documents, and university calendars. Documents from each real-time meeting attended in 1998 were also collected and analyzed.

\section{Analytic method}

Analysis progressed over four phases, using a grounded approach to the data (Strauss and Corbin, 1998). Initially the first author, who collected the data, constructed three within-case narratives (Langley, 1999). These narratives provided thick description of the problems that top managers perceived in getting academics to commit to multiple strategic goals of research, teaching and commercial income. There were tensions between goals that were associated with professional values, such as research and teaching, and 'managerial' values, such as commercial income. However, historical context also had an effect on how academics perceived their main professional goal. For example, at Collegiate, which was historically a research University, research was the main professional goal. At Entrepreneurial research was also core, while at Modern, teaching was the main professional goal. Top managers needed to convince academics to widen their commitment to goals outside their interest in the main professional goal.

Theoretically, we regard managerial rhetoric as part of the everyday practice of managerial action, which may not be obvious to the managers themselves (Giddens, 1984; Heracleous, 2006). Therefore, in the second phase we free-coded the data set, eliciting any rhetorical practices that were associated with the multiple goals in each case. Following Suddaby and Greenwood (2005), we clustered these rhetorical practices according to our three research questions into thematic categories of the dominant rhetorical form being enacted. Thus, under question 1 , we clustered rhetorical practices dealing with how top managers constructed themselves in relation to the academic community, deriving dominant categories of authority rhetoric at Entrepreneurial, powerless rhetoric at Collegiate and powerless-to-change rhetoric at Modern. Under question 2, we 
Jarzabkowski, P. \& J. A. A. Sillince 2007. 'A rhetoric-in-context approach to shaping commitment to multiple strategic goals'. Organization Studies, 28.10: 1639-65.

clustered practices that showed how top managers rhetorically positioned commitment to multiple goals to the audience, deriving dominant categories of reciprocity rhetoric at Entrepreneurial, covert control rhetoric at Collegiate and directive rhetoric at Modern. For question 3, we clustered practices that explained how top managers constructed the context for multiple strategic goals, deriving dominant categories of synergy rhetoric at Entrepreneurial and Collegiate and ambivalentsynergy rhetoric at Modern. Representative examples of these rhetorical categories are presented in the results.

In the third phase, we examined specific incidents in the data, in order to analyze managerial rhetoric in context. Our aim was to validate the managerial practices we identified in situ by analyzing how they were used in combination to shape commitment during top managers' interactions with academics. In particular, given our definition of the rhetorical situation, we examined how the rhetorical forms were used in combination to construct an imperative to act which negotiated the values and interests of the audience and worked with wider contextual issues of history and power. We present a representative incident from each case in order to show how managerial rhetoric occurs in context.

Finally, we undertook a cross-case comparison of the rhetorical practices and their effects within the context of each case. As each case was not starting from the same position in relation to the three goals, we examined contextual reasons for variation in rhetorical practices between the cases. This analysis enabled us to answer our overarching conceptual question about contextual variation in rhetoric and its implications for shaping commitment to multiple goals.

During these four phases of analysis the data were fragmented, compared and reassembled many times which enabled us to be sure that individual data items were not taken out of context and that each rhetorical theme was grounded within the three key data sources, interviews, documents and observations (Strauss and Corbin, 1998). The triangulated data sources, the thick descriptions of rhetoric in context and the first author's deep knowledge of the cases helped to ensure the trustworthiness of the data and analysis (Lincoln and Guba, 1985).

\section{RESULTS}

\section{Case 1: Entrepreneurial University}


Entrepreneurial is a research-led University that is also well regarded and ranked for teaching and has a strong reputation for generating commercial income; "It has a lot of distinction about it in terms of academic excellence. But um, it also has something of a reputation as a go getter, entrepreneurial" (E12). Throughout this study, Entrepreneurial maintained and improved its research and teaching rankings and maintained its percentage of income from non-state sources, generating a consistent surplus in the annual budget. At Entrepreneurial, the imperative for top managers was maintaining academic commitment to multiple strategic goals.

\section{INSERT TABLE 1 ABOUT HERE}

Table 1 presents a representative sample of the three rhetorical practices at Entrepreneurial. In using 'authority rhetoric', top managers position themselves as having legitimate authority over the academic audience (Weber, 1947). For example, they construct an imperative to maintain excellence in which they must "push estimates up", undertake central reviews because they "hate grade 3" and be "tough with academics". This is not unfettered control, as top managers are sensitive to academic norms of autonomy. For example, they appreciate the potential constraint of academic power, acknowledging that "professors still carry power" and that it is important not to make departments "sulky" but keep them "on side". However, even this sensitivity to their audience is tinged with authority rhetoric; not interfering on the academic "patch" is only important when top managers do not perceive a need to interfere. The academics are "troops", whose activities can be harnessed in the services of the University.

With 'reciprocity rhetoric' top managers construct commitment as a reciprocal exchange between the actions that academics perform and the benefits that they receive, a process which facilitates negotiation between top management and their academic audience. For example, acting on the imperative to generate commercial income will give academics "autonomy" because "you can control how it's spent". The undesirable alternative is being subject to top management intervention when there is poor performance. Such rhetoric persuades academics that they will gain benefits to themselves by participating in multiple activities. At the same time, because this is a negotiated process, it establishes obligations based on inducements. For example, the Arts are "beggars" because they are not in a position to make much commitment to the commercial goals. Therefore, they are given "more than their fair share". This casts Arts as not contributing as much 
to the common good, constructing a social obligation that these academics must make other commitments, such as performing well in research. There is strong obligation implied in reciprocity rhetoric; if academics do not perform after having investments made by the University, "serious questions" will be asked.

Reciprocity rhetoric establishes a sense of self-interest within the academic community. Performance of a range of activities, particularly the contentious commercial activity that is outside the traditional academic remit, can benefit the academic. By emphasizing self-interest, reciprocity rhetoric co-opts academics into the commitment process; they become "stakeholders" in the activities of the University. When academics accept these rhetorically-constructed rights and obligations as in their own interests, they give top managers authority over them (Clegg, 1989; Hardy and Clegg, 1996). Hence, the authority and reciprocity rhetorical practices are consistent with each other and mutually reinforcing.

'Synergy rhetoric' constructs a context in which multiple activities are compatible and mutually supportive. It minimizes divergence between goals and achieves a negotiated order by constructing an impression that they are all part of a coherent organizational image of excellence. For example, top managers assert confidently that the strength of academic activities, such as research and teaching, is a "direct result" of financial success. This is not debatable but a "selfevident fact". Synergy rhetoric aggregates multiple goals under the umbrella of an "excellent University". An excellent university is highly ranked in teaching and research. It is able to gain these high rankings because of the commercial activities that "underpin everything we do". Such rhetoric further socializes commitment to multiple goals; an academic can be "proud" of being part of an "excellent University" that "looks good", "produces good students", and additionally meets their self-interest with "reasonable staff: student ratios". Synergy rhetoric emphasizes that these multiple goals are essential to each other and therefore in the academic interest; if an activity that is of lesser-interest to academics were to suffer, then other activities of greater interest would also suffer. Synergy rhetoric thus supports the reciprocity and also the authority rhetoric.

These rhetorical practices at Entrepreneurial are internally consistent and mutually reinforcing. Top managers position themselves confidently as having authority over academics, assert the obligations and rewards associated with multiple goals and construct a context of synergy 
Jarzabkowski, P. \& J. A. A. Sillince 2007. 'A rhetoric-in-context approach to shaping commitment to multiple strategic goals'. Organization Studies, 28.10: 1639-65.

between these goals. The academic audience is constructed as aware of top managers' legitimacy by authority rhetoric, as negotiation partners by reciprocity rhetoric, and supportive of the mutual interests arising from multiple goals. The combined effect of these three rhetorics is an overall assertive influence which constructs an imperative to act, negotiates the interests of the academic audience and works within the historical and political context of the organization. This is now illustrated using a specific incident.

$\underline{\text { Rhetoric in context: Widening Science's commitment to multiple goals }}$

This vignette explains how top managers widened commitment in the 'Sciences' department ${ }^{2}$ to encompass commercial goals. 'Sciences' has been the target of investment over the preceding years and now performs very strongly in research and teaching. Top management rhetoric about Sciences endorses the synergies between research and teaching: "Five years ago nobody knew much about Sciences. It had some moderate difficulty filling its places. Then it got a $5 *$ in research and then it got 24 on teaching quality [the highest possible score] and now it's got student applications coming out of its ears. It can't move. So the marketplace knows what to look for" (E9). As Sciences is a star performer it has earned the autonomy that arises from meeting obligations to particular goals. For example, Sciences was one of only three departments that did not have a research review 'conducted' by top managers following the 1996 national Research Assessment Exercise (RAE) (Strategy Committee minutes, 1997).

As 'Sciences' is performing so well, top managers decide to invest in a new building that will enhance student recruitment and, particularly, research excellence: "In the big picture, Sciences will provide better returns than [other investments] in terms of the RAE” (Strategy Meeting, 1998). However, a combination of reciprocity and synergy rhetoric indicates dissatisfaction with Sciences' commercial performance, constructing an imperative to act; "They have got to agree to pursue strategies in regard to both students and research that will benefit the University financially as well as academically" (E1). By not meeting its obligation to commercial activities, Sciences is jeopardising the synergy between commercial activity and teaching and research. Sciences has therefore lost its right to autonomy and top managers have authority to intervene in its performance.

\footnotetext{
2 'Sciences' is a department within the Science faculty
} 
Jarzabkowski, P. \& J. A. A. Sillince 2007. 'A rhetoric-in-context approach to shaping commitment to multiple strategic goals'. Organization Studies, 28.10: 1639-65.

Top managers tie Sciences into a full fee-paying professional course with income targets in return for the investment in their building. This indicates the combined assertive influence of managerial rhetoric. The initial reason for giving Sciences a building was that investment in facilities would help the University to strengthen key strategic areas of teaching and research. However, the obligations associated with the new building are being expanded beyond teaching and research to encompass commercial goals. Top managers are convinced that these are synergistic activities and that reciprocity is a fair expectation from Sciences. For example, when an academic queries; "Are we giving Sciences the building because we want a $5 *$ department or because we want profit maximization? It seems we want it all" (Strategy meeting), the Vice-Chancellor asserts that "We want BOTH", using authority rhetoric to confirm that top managers have the right to expect both because these are synergistic goals, pointing out that, historically; "The [commercial] activities have added to the profile of the University, not robbed from teaching and research" (VC in Strategy meeting). This provides rhetorical closure to the debate about whether multiple goals are divergent. They are positioned as mutually supportive, therefore Sciences has an obligation to perform all strategic goals in order to support the University and earn rights and rewards.

The team realize that they must negotiate academic values and interests, as Sciences will resist commercial activity because their performance in teaching and research has afforded them autonomy; "It's very difficult to persuade our colleagues in that department that they should do anything different" (Strategy Meeting). However, top managers exert authority rhetoric to exact commitment from Sciences. Their rhetoric positions the new building not as a strategic means for the University to secure its future teaching and research goals but as a benefit to Sciences. The University's interests in investing in Sciences are suppressed as top managers' rhetoric constructs the building as in Sciences' interests and therefore involving obligations from Sciences. Top managers thus use a combination of authority, reciprocity and synergy rhetoric to socially construct a widened arena of commitment, creating a sense of obligation to commercial activities, whilst using the inducement of investment to motivate Sciences. This effort by top managers works, as Sciences not only accept the professional course but also propose their own ideas on additional commercial activities they could run. While these ideas need development to become truly profitable, top managers feel that "this represents a psychological breakthrough" in commitment 
Jarzabkowski, P. \& J. A. A. Sillince 2007. 'A rhetoric-in-context approach to shaping commitment to multiple strategic goals'. Organization Studies, 28.10: 1639-65.

from Sciences (Income meeting). The financial inducement of a building has been a key physical aspect of this commitment but the positioning of this inducement is grounded in the internally consistent, authoritative rhetorical practices used by top managers.

\section{Case 2: Collegiate University}

Collegiate may be characterized by typical views of universities as 'organized anarchies' (Cohen and March, 1986), having a strong tradition of academic autonomy and avoiding overt control. Research is the core strategy of the University and this is fiercely protected by academics, who fear that other activities will detract from research; "the pressures on academic life are squeezing research time out. We're vulnerable there. We're vulnerable to losing research excellence" (C10). However, Collegiate is also improving quality and service-delivery in teaching programmes and developing some commercial activities, despite this being a particularly contentious goal because of potential conflict with research: "There are people who strongly resent the idea that an academic institution should want or need to engage in [commercial] activities which they see as rather low status and dubious" (C14). Collegiate is thus making some progress towards commitment to multiple goals, albeit that this is not yet general organizational acceptance. The managerial imperative is that "The excellence which we have, is balanced precariously on too small a resource base and action MUST be taken on the resources in the near future" (C4).

\section{INSERT TABLE 2 ABOUT HERE}

Table 2 presents a representative sample of the three rhetorical practices at Collegiate University. Through 'powerless rhetoric' top managers construct themselves in relation to an academic audience with strong collegial norms. Top managers have little power over academic actions, particularly in the core activity, research, where it is "hands off'. Rhetorically, top managers perpetuate deference to their audience's collegial norms, accepting that "directive" intervention is not an option for shaping academic commitment, as academics "didn't come to Collegiate to be treated like that". Indeed, trying to gain centralized control is not even a possibility; "It would be very difficult to do here". If top managers attempt control, they will "come unstuck" and raise greater resistance, as academics will "disagree for the hell of it". Powerless rhetoric thus positions academics as powerful and free to pursue their own interests, while 
Jarzabkowski, P. \& J. A. A. Sillince 2007. 'A rhetoric-in-context approach to shaping commitment to multiple strategic goals'. Organization Studies, 28.10: 1639-65.

constructing top managers as unable to exact commitment from these academics through hierarchical means.

However, accompanying powerless rhetoric, we also found 'covert control rhetoric'. Covert control rhetoric positions top managers as having agency, providing that they accept political constraints by not disturbing collegial norms of academic autonomy. It is important not to be "managerial" but to "work the system" to negotiate informally. Through covert control, top managers can "command resources" and "get their way" through alternative techniques, such as "persuasion" and getting academics "to think that they want what we want". Indeed, covert control rhetoric positions top managers powerfully with regard to their audience; they are able to "run the place" and get the committees "to do what we want". Matching powerless rhetoric with covert control rhetoric establishes a sphere of influence for top managers to negotiate commitment with academics. As they are powerless to influence academics through their hierarchical position, they exercise influence through the tools of persuasion, such as "explaining the enormity" of issues. If they disturb norms of academic autonomy, they will be powerless but if they are persuasive, they may establish covert control by convincing academics that they are acting in their own interests (Clegg et al, 2006; Hardy, 1996; Lukes, 1974). Academics must be persuaded to commit to multiple goals by perceiving that all of those goals are within their interests (Davenport and Leitch, 2005).

Through 'synergy rhetoric', top managers construct a context of multiple goals. At Collegiate synergy rhetoric, while serving a similar purpose of constructing coherence between potentially divergent goals as at Entrepreneurial, is different in tone. It is persuasive, convincing academics that multiple goals are "in their interests" and will not "compromise academic integrity". At the same time, they are careful not to offend collegial norms, using synergy rhetoric to minimize any perception of threat to academic activities such as research. For example, while improving teaching quality is important, it will not replace "the quality of one's research". Similarly, the contentious commercial activity "is not at variance with the core business [research]". Rather, it will support research by "paying for research time”. Synergy rhetoric constructs a convincing argument directed at the academic audience, such as "re-badging programmes" which academics are not interested in to give them more appeal, so persuading academics to accept those activities, while being sensitive to collegial norms. 
Jarzabkowski, P. \& J. A. A. Sillince 2007. 'A rhetoric-in-context approach to shaping commitment to multiple strategic goals'. Organization Studies, 28.10: 1639-65.

The three rhetorical practices at Collegiate have an internally consistent persuasive rhetorical influence, enabling top managers to negotiate around their powerlessness and providing them with covert control by convincing academics that commitment to multiple goals is within their interests. Through combined rhetoric, the audience is consistently constructed as resistant to overt power but able to be manipulated through persuasion. As the following vignette illustrates, top managers are thus able to exert a persuasive rhetorical influence over academic commitment to historically unacceptable goals.

$\underline{\text { Rhetoric in context: Widening commitment to commercial activities }}$

This vignette explains how top managers' rhetoric widens organizational commitment to encompass commercial activity. As commercial income is increasingly important to the University's survival, top managers wish to grow commercial programs under the title 'Professional Studies'; a marketplace that could be lucrative. However, they recognize that, historically and politically, this will be seen as interfering with research; "The work that they do on these short courses ... could have been spent on key books and articles" (C11). Therefore they must use covert controls to widen commitment to commercial goals without disturbing collegial norms that could raise resistance and leave them powerless to have an effect.

Synergy rhetoric constructs alignment between the commercial strategy and the elite research reputation of the institution. For example, at Academic Board commercial programs are tabled as "1. To service a market sector requiring continuing education of the highest quality within professional accreditation norms; 2. To secure an important new income stream for the University and for Departments; and 3. To provide an attractive "shop window" for the University and to project its image as an elite institution offering high quality and high-relevance research-led teaching". Rhetoric reinforces synergies of 'quality' between the commercial and research goals. At the same time, top managers argue convincingly for the validity of commercial programs in the University context. They explain that commercial programs are consistent with the original research mission of the University (Calendar), which is to engage in the affairs of government and industry. Top managers invoke this mission to build synergy between the historical research goals and the current commercial goals. In a Planning meeting, they discuss the importance of synergy rhetoric in 
Jarzabkowski, P. \& J. A. A. Sillince 2007. 'A rhetoric-in-context approach to shaping commitment to multiple strategic goals'. Organization Studies, 28.10: 1639-65.

changing organizational attitudes about the meaning of the core research business; "Sometimes things just need to be re-labeled to rejuvenate their popularity".

Top managers are aware of their powerlessness to influence academics, except through persuasion that this is in their interests. For example, at Academic Board, a leading academic raises academic fears: "Is this going to be a situation where academics are bludgeoned into teaching these courses to the detriment of research and promotion opportunities?" The VC disarms the potential confrontation, reiterating Collegiate's history of relevance to industry and providing reassurance about compatibility to the elite research reputation. Rhetoric directs academic attention away from managerial control, which might raise resistance, guiding it towards synergy with academic research interests. This rhetoric is effective, as the Academic Board accepts the proposal to offer Professional Studies. Academics have been persuaded that it is consistent with the University's elite reputation; "As long as we stick to highly academic courses we'll do well in the market. We have good strengths. Let us build upon those and not chase our tails on something not central to our ethos and tradition of excellence" (Academic at Academic Board). Academics have widened their commitment to accept "the market" because it is in their research interests and they do not feel that their academic autonomy has been compromised. Through the internal consistency of their rhetoric, top managers have negotiated around their powerlessness to control academics and had a persuasive rhetorical influence over academic commitment.

\section{Case 3: Modern University}

Modern has a reputation for excellent and innovative teaching; "Modern's heartland is teaching and learning" (M5). While some academics pursue research, the historical view is that "strategically we couldn't be a research University" (M7). Similarly, historically, "entrepreneurial activity and income generation are not integrated into the ethos of the institution" (Coopers and Lybrand report, 1988). While the core activity of the University has been teaching, the changing higher education environment has put increasing pressure on Modern to also embrace research and commercial goals. Modern is thus undergoing the most contextual change, in which the imperative for top managers is to define the institution as a University and develop a portfolio of strategic goals. 
Table 3 presents a representative sample of the three rhetorical practices at Modern. In 'powerless-to-change' rhetoric top managers express the enormity of their task in changing the attitudes of academics to encompass commercial and research goals. Their rhetoric constructs them as powerless in relation to the resistant academic audience, who are sometimes described as "backwoodsmen and women". Academics are "not hungry" for change, do not "believe in the market" and want things to be "exactly as it is at the moment". This powerlessness is different than at Collegiate. At Modern, the constraint is lack of power to change obdurate academic attitudes, which are cast as opposing those of top managers. For example, there is a "them and us culture", in which top managers have good ideas but cannot get departments "on board to actually do it". Top managers are powerless in terms of the mammoth change ahead with such a recalcitrant academic body.

In contrast to their powerless-to-change rhetoric, top managers also display 'directive rhetoric', in which they position their academic audience ${ }^{3}$ as willing to accept direction to change. The imperative to achieve new goals is expressed in uncompromising terms. For example, departments are told "we want you to address research", while on international students "we want to double numbers" and "we expect departments to double or treble the money they get". While top managers use directive rhetoric, this rhetoric is inconsistent with the way they construct themselves in powerless-to-change rhetoric. On the one hand they have an academic audience that is resistant to change, while on the other hand they direct this audience to undertake a range of major changes. It will be difficult to motivate academics to make the major commitment necessary to "address research", "double numbers" and "double or treble money", if academics "can't see why they should do" activities of this nature. There is thus rhetorical inconsistency towards the audience.

Rhetorical inconsistency is further evidenced in the 'ambivalent synergy rhetoric' used to construct a context for multiple strategic goals, as top managers show ambivalence; sometimes claiming that activities are synergistic and at other times displaying doubt about these synergies. For example, they make synergistic claims that research "underpins teaching" and "brings in resources". However, they also claim "a real contradiction" because research brings prestige but

\footnotetext{
${ }^{3}$ Directive rhetoric is different from the 'authority rhetoric' at Entrepreneurial because it lacks the legitimacy with academics; authority is legitimate power vested in particular people or positions for system purposes (Weber, 1947).
} 
Jarzabkowski, P. \& J. A. A. Sillince 2007. 'A rhetoric-in-context approach to shaping commitment to multiple strategic goals'. Organization Studies, 28.10: 1639-65.

does not "bring the overheads". These inconsistencies create confusion about the imperative for research; whether it is to develop the University's prestige or to be a source of commercial income, leading to the sarcastic query; "What are we trying to generate, research money or real money?" These rhetorical inconsistencies create a crucial constraint to top management influence because they construct commitment to teaching, research and commercial income as a zero-sum game. This inevitably constructs resistance to change because, in order to make a greater commitment to one of these goals, academics must sacrifice commitment to some other goal. For example, in order to do more research, it will be necessary "to thin out teaching", while resources that are put into research will "detract" from teaching. Given their existing strong commitment to teaching, this makes multiple goals unattractive for academics. Top managers construct a context in which it is impossible for academics to commit equally to all of their directives.

The three rhetorical practices at Modern are internally inconsistent, so that, in combination they constitute an overall contradictory rhetorical influence, in which powerless-to-change rhetoric contradicts directive rhetoric, while ambivalent synergy rhetoric generates contradictions between goals. Rhetorically, the audience is inconsistently constructed as resistant to change, willing to be directed to change and unable to perform multiple goals. This contradictory influence is now illustrated using a specific incident.

$\underline{\text { Rhetoric in context: Constructing zero-sum commitment }}$

This vignette explains top managers' contradictory rhetorical efforts to shift academic commitment from teaching activities towards research and commercial goals. Top managers recognize that teaching is the core academic activity; "It does as an institution take itself very seriously about being student centred" (M5). In order to shape commitment to other goals, top managers take a directive stance, implementing "staff time efficiency gains through a saving of 10 to $20 \%$ of formal teaching responsibilities and 10 to $20 \%$ of assessment time. These savings may then be used to redeploy resources into strategic priority areas" (Planning cycle documents). Building on these efficiency gains, top managers engage in further directive rhetoric about restructuring the academic teaching year from three 11-week terms into two semesters in order to make time for other activities; "It's that which is driving some of the things about changing the shape of the academic year because if you're going to do research ... you need time" (VC). 
The team attempt to position this change as a way to free commitment from teaching. However, they display ambivalent synergy rhetoric, asserting that; "We are now moving in the direction where research is going to be a much bigger part of our profile" (VC), whilst even the DVC for research worries that; "The last thing we want is for teaching to suffer". This ambivalence persists even when top managers are presenting the restructuring of the academic year to the final committees for decision. They are aware that this proposal impinges on academics' core professional activity; "The structure of the academic year and the kind of hot air that it's generating on Academic Board is quite interesting. It's a kind of touchstone for things that really are felt deeply" (M2). Nonetheless, at the meetings with academics to decide upon the change, they first present their two semester option, explaining how this will not harm teaching but will provide more time to undertake research and commercial activities. Then they make ambivalent statements when the issue is opened to discussion. For example, one top manager queries whether the residential income lost through less student attendance can be counteracted by the commercial income gained from redeploying staff time. Another suggests that a big structural change at this time might distract people from research. Yet another manager supports the change as it meets the objective of freeing time for research, consultancy and short courses.

Even in front of an academic audience in whom they are attempting to instil commitment, top managers' rhetoric is inconsistent, presenting both strong synergy between multiple goals and ambivalence about their synergies. The combined rhetorical influence is unconvincing, as academics perceive that commitment to these other goals means teaching must suffer. They reject the two semester option and vote to take the least disruptive restructuring of their teaching year, which is three 10-week terms, justifying their decision on the basis that anything else would be detrimental to "the students and their rights and needs" (Planning cycle meeting). Through their rhetorical inconsistency, top managers have had a contradictory rhetorical influence that is not able to achieve academic commitment to multiple goals.

\section{DISCUSSION: RHETORIC IN CONTEXT}

These results have answered the three questions that guided the empirical study: how top managers construct themselves rhetorically in relation to their audience; how they position commitment to multiple goals rhetorically to that audience; and how their rhetoric constructs a 
Jarzabkowski, P. \& J. A. A. Sillince 2007. 'A rhetoric-in-context approach to shaping commitment to multiple strategic goals'. Organization Studies, 28.10: 1639-65.

context for academic commitment to multiple strategic goals. In the discussion these results are drawn together in order to address the overarching conceptual question; How does top managers' rhetoric vary in different contexts and what implications does this variation have for the rhetorical construction of commitment to multiple strategic goals? We conceptualized context within the long duration of an organisation, instantiated in and modified through the rhetorical negotiations of context when actors interact (Giddens, 1984; Heracleous, 2006). As each case was in a different historical context of commitment to multiple goals, we undertook a cross-case comparison of the relationship between historical context and rhetorically instantiated context when top managers interact with academics about commitment to multiple goals. The results of this cross-case comparison, summarized in Table 4, are now discussed.

\section{INSERT TABLE 4 ABOUT HERE}

First, comparison of the specific rhetorical practices used highlights the importance of synergy rhetoric for constructing a context of commitment to multiple goals. Top managers at both Entrepreneurial and Collegiate used synergy rhetoric to invoke favourable associations between goals. They persuaded academics to widen commitment beyond their professional interests in goals such as research by constructing synergies with other goals, such as commercial income, which could serve their interests by providing more money for research. Synergy rhetoric thus played upon the calculative elements of commitment by emphasizing the self-interest involved in commitment to multiple goals (Fligstein, 1997; Mackin, 1996; Siders, George \& Dharwadkar, 2001). Such calculative elements may also develop a normative, socialized character, as organizational members cease to expect immediate gratification, accepting that certain actions are within their general interests (Blau, 2002; Constant, Sproull and Kiesler, 1996). Synergy rhetoric also played upon these socialized elements of commitment by emphasizing how multiple goals could enhance the University's prestige and reputation, guiding their performance towards the broader interests of the organization. By contrast, top managers at Modern were ambivalent in their rhetoric about synergy between goals, which was unconvincing in persuading academics to embrace goals outside their professional interests in teaching. Ambivalent synergy rhetoric invoked a context in which greater commitment to one goal meant less commitment to another, providing little 
incentive for academics to sacrifice their existing interests to embrace additional goals. Synergy rhetoric is thus particularly important in constructing a context of commitment to multiple goals.

Second, comparisons show a relationship between the historical context of commitment to multiple goals and the way top managers instantiated their rhetorical influence in negotiations about academic commitment to these goals. Top managers at Entrepreneurial did not need to invoke organizational change, as historically commitment to multiple goals was established, albeit that some departments, such as Sciences, might require selective widening of commitment. This historical context enabled top managers to instantiate an assertive rhetorical influence in interactions with academics. They had the authority to intervene in academic actions, could extract obligations from academics to commit to activities in a reciprocal relationship with awarding rights to those academics and could assert, factually, that the synergy between activities was in the academic interest. Top managers' combined rhetoric was embedded within and could instantiate the historical context of multiple goal performance in order to both maintain that context and convincingly exert influence with those departments that deviated from performing some goals.

By contrast, historically a multiple goal context was not established at Collegiate, although acceptance of commercial activities and teaching quality and services was growing. Furthermore, in this context historically strong collegial norms made it difficult to invoke change through a rhetoric of management fiat. Rather, top managers had a persuasive rhetorical influence, instantiating a changing context by convincing academics that multiple goals were in their interests and that they would support, not harm, the core academic activity of research. The historical context of this case is markedly different from the context at Entrepreneurial both in terms of the degree of contextual change needed and the strong professional norms that governed how that change might be achieved.

Historically, the context at Modern was least characterised by multiple goals. Multiple goals represented a fundamental change from their historical position as a teaching institution to an uncertain position as a University with a portfolio of strategic goals. Top managers had few contextual resources to draw upon in defining that change to the academic audience. As they tried to work out the scope of the change, they constructed a contradictory rhetorical influence, oscillating between positioning themselves as powerless to generate change in an obdurate academic body and directing those academics to undertake major change such as doubling student 
Jarzabkowski, P. \& J. A. A. Sillince 2007. 'A rhetoric-in-context approach to shaping commitment to multiple strategic goals'. Organization Studies, 28.10: 1639-65.

numbers and doubling or trebling income. At the same time, they contradicted themselves about the synergy between activities, sometimes presenting strong synergies and at other times expressing ambivalence about these synergies. Without a supportive historical basis to work from, top managers' rhetoric was embedded in contextual uncertainty about the implications of sectoral change, and this uncertainty was instantiated in the way they constructed themselves, how they positioned multiple goals to the audience and their inability to construct a receptive context for those goals. This fundamental change in the historical basis of the University was reflected in the internal inconsistency of top managers' rhetoric about the new, multiple-goal context.

These findings make two main contributions. First, they indicate that managerial rhetoric is not acontextual. Rather, our comparisons illustrate that rhetoric is grounded within and derives meaning and legitimacy from the historical context in which it is invoked (Vaara et al, 2001). For example, at Entrepreneurial top managers construct themselves as having legitimacy to assertively intervene, but this authority rhetoric is grounded within and attains legitimacy from the context in which it is uttered, whereas a similar rhetoric would lack meaning in the Collegiate context and would lack legitimacy with the audience. At Collegiate top managers only have the legitimacy to tactfully persuade academics. The long duration of organizational context thus constrains the rhetorical positions taken by top managers, even as it provides meaning and legitimacy to what they say that enables them to change that context (Giddens, 1984; Heracleous, 2006). In order to instantiate a meaningful rhetorical context, top managers must draw upon concepts that are understood and have legitimacy within the social order of the organization (Hardy et al, 2000; Lueger et al., 2005). Thus top managers at Modern find it difficult to instantiate a context of multiple goals because their rhetorical approach indicates that teaching will assume a less central role, which is counter to the historical legitimacies of teaching as the core academic activity. The presence of long duration context in any specific incidence of rhetorical context does not mean change is impossible, but does shape how that change can be constructed. For example, top managers at Collegiate are able to construct a context of multiple goals by building rhetorical links that indicate how other activities will support, not devalue the legitimacy of research as the core academic activity. The relationship between rhetoric and context is not deterministic, as the cases illustrate that, rhetorically, top managers are able to shape change but must do so in ways that are 
Jarzabkowski, P. \& J. A. A. Sillince 2007. 'A rhetoric-in-context approach to shaping commitment to multiple strategic goals'. Organization Studies, 28.10: 1639-65.

legitimate within the context being changed. While other research increasingly indicates a relationship between rhetoric and context (e.g. Hardy et al, 2000; Heracleous, 2006; Sillince, 2005; Suddaby and Greenwood, 2005), the cross-case comparisons here elaborate and extend this relationship. We show that rhetoric varies according to the historical context of the organization, the amount of change it is undergoing, and the legitimacies accorded to aspects of that change by the audience.

Our second contribution is the importance of internal consistency within top managers' rhetoric, which is related to their ability to influence their audience. We have illustrated that rhetoric does not consist of isolated statements or a single predominant type by showing the association between rhetorical forms when rhetoric is used in context. Managerial rhetorical practices have a combined influence in situ, which must be considered for its internal consistency. Other research has hinted at the importance of rhetorical consistency. For example, Phillips et al. (2004) suggest that when rhetorics contradict each other their implications for action are more negotiable and hence they are less likely to produce institutions. Scholars have noted the importance of consistency between internally and externally directed organizational rhetoric (Christensen and Cheney, 2001). Sillince (2005) argued that rhetorical congruence increases the likelihood of successful action. Rhetorical congruence exists first if rhetoric is appropriate to contextual contingencies and, second, if the various rhetorical processes are in balance with one another. It therefore appears that the effectiveness of rhetoric lies not only in its grounding in historical context but also in the consistency between specific rhetorical practices within the immediate context of its use (Heracleous, 2006; Sillince, 1999b; 2005). Our findings support and extend these suggestions by showing that rhetorical consistency is associated with top managers' ability to construct a context of commitment to multiple strategic goals. Rhetoric cannot be taken out of context either in terms of the long duration of organizational context in which it is instantiated or the inter-textual way in which it is associated with other rhetorical forms within the specific context of interaction. Our findings thus confirm and elaborate a multi-level approach to discourse context (e.g. Fairclough 2001; Keenoy et al, 1997; Phillips et al, 2004) by indicating the importance of internal consistency between rhetorical forms in constructing a context, as well as their consistency with the wider organizational context in which they are used. 
Jarzabkowski, P. \& J. A. A. Sillince 2007. 'A rhetoric-in-context approach to shaping commitment to multiple strategic goals'. Organization Studies, 28.10: 1639-65.

\section{CONCLUSIONS}

This paper makes three main contributions to existing literature. First, it extends theory about how organizational members are persuaded to commit to the organization and its goals as a whole (e.g. Chreim, 2002; Fiol, 2002; Reger et al, 1994) by examining the problem of commitment to multiple organizational goals. We have shown that, in the context of multiple goals, rhetoric is a valuable resource because it can persuade organizational members that there are links between goals that they already value and goals that might otherwise be seen as divergent from their interests. Furthermore, we have shown that top managers' influence over commitment will be enhanced where they use internally consistent rhetorical forms that are grounded within the historical context in which they are invoked. Rhetoric analysis thus provides a more fine-grained understanding of influencing commitment to multiple rather than single strategic goals. These findings elaborate and extend existing theory on commitment, providing the basis for future research into the role of rhetoric in influencing commitment to multiple goals across a wider sample of cases.

Second, by linking variation in rhetoric to variation in context the paper addresses calls to extend the use of rhetorical analysis in organization theory (Heracleous, 2006; Sillince, 1999a, 2002 , 2005). Our study shows how rhetoric varies between contexts depending upon the degree of change needed to establish multiple goals within those contexts and the historical legitimacies accorded to different goals. Furthermore, we have shown that specific rhetorical practices are not isolated but must be considered in terms of their rhetorical consistency. While specific rhetorical practices are sensitive to context and thus show variation between contexts, our findings suggest that the way internal consistency of rhetoric constructs context may also be more generalizable across cases. Future research could further elaborate our findings about rhetoric and its variation between contexts as well as examining its similarities across contexts.

Third, our findings provide a contextually-grounded approach to rhetoric that is of methodological value. It has been argued that the neglect of historical and social context in discourse research has reduced its capacity to explain how individuals use and relate to discourse (Heracleous, 2004; 2006; Heracleous and Marshak, 2004). Our paper addresses this criticism by providing a structured approach to analysing rhetoric in context in ways that illustrate its relevance 
and application to both organizational context and to actors' concerns to influence commitment to organizational goals.

The findings from this study have implications for practice. Managers in pluralistic contexts such as universities, which typically have diffuse power relationships and multiple and ambiguous goals, are under increasing external pressure to generate a coherent strategic response from their organizations, whilst being constrained in their ability to act by management fiat. Managers in such contexts might use our findings to reflect upon their rhetorical positioning in relation to their audience, the contextual application of their rhetoric, and their rhetorical consistency. They might thus enhance their influence over employee commitment in contextually-sensitive ways.

A limitation of this study is its single sector setting. However, in keeping with other professional organizations, such as hospitals, cultural organizations and professional service firms, universities tend to have diffuse power relationships, low capacity to act by management fiat (Denis et al, 2001) and to deal in knowledge-based outputs (Hinings and Leblebici, 2003). In particular, as organizations are becoming increasingly fluid (Rindova and Kotha, 2001) and as knowledge-based work is increasingly important in many industries (Løwendahl \& Revang, 1998), our findings might be expected to have relevance to many organizations that share characteristics with universities.

\section{REFERENCES}

Aristotle, 2000, The Art of Rhetoric, Freese J.H., (trans), Boston: Harvard University Press

Bakhtin Mikhail.M.,

1981, 'Epic and novel: toward a methodology for the study of the novel', 3-40 in Holquist M., (ed), The dialogic imagination: Four essays by M.M.Bakhtin, University of Texas Press, Austin TX.

Biesecker, Barbara.A.

1999. Rethinking the rhetorical situation from the thematic of Difference. 232-246 in Lucaites,

John.L., Condit, Celeste.M. and Caudill, Sally.

Contemporary rhetorical theory: a reader. New York. Guilford Press. 
Bitzer, Lloyd.F.

1999. The rhetorical situation. 217-225 in Lucaites, John.L., Condit, Celeste.M. and Caudill, Sally. Contemporary rhetorical theory: a reader. New York. Guilford Press.

Blau Peter.M., 2002, Exchange and power in social life, Transaction, New Brunswick.Burke, Kenneth. 1969. A Rhetoric of Motives. Berkeley. University of California Press.

Cheney George., Christensen Lars.T., Conrad Charles., and Lair Daniel.J., 2004, 'Corporate rhetoric in organizational discourse', 79-103 in Grant David., Oswick Cliff., Hardy Cynthia., \& Putnam Linda.L. (eds), Sage Handbook of organizational discourse, London: Sage.

Chreim, Samia.

2002. Influencing organizational identification during major change: a communication-based perspective. Human Relations. 55 (9): 1117-1137.

Cheney George., and Christensen Lars.T., 2001, 'Organizational identity', 231-269 in Jablin F.M., and Putnam L.L., 2001, Handbook of organizational communication: advances in theory, research and methods, Sage, Thousand Oaks CA.

Clegg, Stewart.

1989. Frameworks of Power. London: Sage.

Clegg, Stewart., David. Courpasson, \& Nelson. Phillips. 2006. Power in Organizations. Thousand Oaks, CA: Sage, forthcoming. 
Cohen, Michael. D. and March, James. G.

1986. Leadership and Ambiguity. New York: McGraw-Hill.

Constant, David., Sproull, Lee., and Kiesler, Sara.,

1996,. 'The kindness of strangers: The usefulness of electronic weak ties for technical advice', Organization Science, 72, 119-135.

Davenport, Sally. and Leitch, Shirley.

2005. 'Circuits of power in practice: strategic ambiguity as delegation of authority'. Organization Studies. 26(11): 1603-1624.

Denis, Jean-Louis; Lamothe, Lisa and Langley, Ann.

2001. The Dynamics of Collective Leadership and Strategic Change in Pluralistic Organizations. Academy of Management Journal, 44, 4: 809-837.

Denis, Jean-Louis; Langley, Ann; and Rouleau, Linda. 2006.

Strategizing in pluralistic contexts: Rethinking theoretical frames. Human Relations, Forthcoming.

Fairclough, Norman.

2001. Language and power. Harlow, England, Longman.

Fiol, C.Marlene.

2002. Capitalizing on paradox: the role of language in transforming organizational identities.

Organization Science. 13 (6): 653-667.

Fligstein, Neil.

1997 'Social skills and institutional theory'. American Behavioral Scientist, 40 (4): 397-406.

Floyd, Steven.W., and Lane, Peter.J., 
2000, 'Strategizing throughout the organization: management of role conflict in strategic renewal', Academy of Management Review, 25 (1), 154-178.

Giddens Anthony.,

1984, The constitution of society, University of California Press, Berkeley CA.

Hardy, Cynthia.

1996. Understanding Power: Bringing About Strategic Change. British Journal of Management. 7 , Special Issue: 3-16.

Hardy, Cynthia. \& Clegg, Stewart.R.

1996. Some Dare Call it Power. In S.R. Clegg, C. Hardy, \& W.R. Nord (Eds.), Handbook of Organization Studies. (pp. 622-641). London: Sage

Hardy, Cynthia. \& Fachin, R. C.

1990. Managing Strategy in Academic Institutions: Learning from Brazil. Berlin and New York: W. de Gruyter.

Hardy, Cynthia, Palmer, Ian and Phillips, Nelson.

2000. Discourse as a strategic resource. Human Relations, 53: 1227-1248.

Heracleous, Loizos., \& Barrett, Michael.

2001. Organizational change as discourse: Communicative actions and deep structures in the context of information technology implementation. Academy of Management Journal, 44: 755 778.

Heracleous, Loizos. and Marshak, Robert.J.

2004. Conceptualizing organizational discourse as situated symbolic action. Human Relations. 57

(10): $1285-1313$. 
Heracleous, Loizos.

2004. Interpretive approaches to organizational discourse. 175-192 in Grant David., Oswick Cliff., Hardy Cynthia., \& Putnam Linda.L. (eds), Sage Handbook of organizational discourse, London: Sage.

Heracleous, Loizos.

2006. A tale of three discourses: the dominant, the strategic and the marginalized. Journal of Management Studies. Forthcoming.

Hinings, C. R. (Bob) \& Leblebici, Huseyin.

2003. Editorial Introduction to the Special Issue: Knowledge and Professional Organizations. Organization Studies 24, 6: 827-30.

Iedema, Rick.

2003 Discourses of post-bureaucratic organization. Amsterdam, John Benjamins.

Jackall, Robert.,

1988, Moral mazes: the world of corporate managers, Oxford University Press, Oxford.

Jarzabkowski, Paula.

2003. 'Strategic practices: An activity theory perspective on continuity and change. Journal of Management Studies, 40/1: 23-55.

Jarzabkowski, Paula.

2005. Strategy as Practice: An Activity-Based View. UK: Sage.

Jarzabkowski, Paula., Balogun, Julia \& Seidl, David, 2007. Strategizing: The challenges of a practice perspective. Human Relations, forthcoming. 
Korsgaard, M.Audrey., Schweiger, David.M., and Sapienza, Harry.J.,

1995, 'Building commitment, attachment, and trust in strategic decisions', Academy of Management Journal, 38 (1), 60-85.

Langley, Ann.

1999. Strategies for theorizing from process data. Academy of Management Review, 24, 4, 691-710.

Lilley S.

2001, 'The language of strategy', 66-88 in Westwood R. and Linstead S., (eds) Language of organization, Sage, London.

Lincoln, Yvona.S. \& Guba, Egon.G.

1985. Naturalistic Inquiry. London: Sage.

Linstead Stephen

2001, 'Rhetoric and organizational control: a framework for analysis', 217-241 in The language of organizations, R.Westwood, and S.Linstead, (eds), London, Sage.

Lowendahl, Bente. \& Revang, Oivind.

1998. Challenges to existing strategy theory in a post-industrial society. Strategic Management Journal, 19, 8, 755-774.

Lueger, Manfred., Karl. Sandner, Renate. Meyer \& Gerhard. Hammerschmid.

2005. Contextualizing Influence Activities: An Objective Hermeneutical Approach. Organization Studies 26(8): 1145-1168

Mackin C., 1996, Ownership theory: Rights and responsibilities of ownership. Annual report. La Jolla, CA: 
Foundation for Enterprise Development.

Middleton-Stone, Melissa. \& Brush, Candida. Greer.

1996. 'Planning in ambiguous contexts: The dilemma of meeting needs for commitment and demands for legitimacy'. Strategic Management Journal, 17: 633-652.

Mueller Frank., Sillince John.A.A., Howorth Chris., Harvey Charles., 2004, 'A rounded picture is what we need': rhetorical strategies, arguments and the negotiation of change in an NHS Hospital Trust', Organization Studies, 25 (1), 85-104.

O’Leary, J. (Editor.)

1997. The Times Good University Guide: 1997. London: Times

Phillips, Nelson., Lawrence, Thomas.B. and Hardy, Cynthia.

2004. Discourse and institutions. Academy of Management Review. 29 (4): 635-652.

Pierce, Jon.L., Kostova, Tatiana., and Dirks, Kurt.T., 2001, 'Toward a theory of psychological ownership in organizations', Academy of Management Review, 26 (2), 298-311.

Potter, Jonathan. and Wetherell, Margaret.

1987. Discourse and social psychology: beyond attitudes and behaviour. London, Sage.

Reed, Michael.

1998. Organizational analysis as discourse analysis: a critique. In Grant, David., Keenoy, Tom. and Oswick, Cliff. Discourses + organization. London. Sage.

Reger, Rhonda.K., Gustafson, Loren.T., Demarie Samuel.M., and Mullane, John.V., 
1994, 'Reframing the organization: why implementing total quality is easier said than done', Academy of Management Review, 19 (3), 565-584.

Rindova, Violina. \& Kotha, Suresh.

2001. Continuous "morphing": Competing through dynamic capabilities, form, and function. Academy of Management Journal. 44.6: 1263-1281.

Schaffer, Utz., and Willauer, Bianca., 2003, 'Strategic planning as a learning process', Schmalenbach Business Review, 55 (2), 86-108.

Siders Mark.A., George Gerard., and Dharwadkar Ravi., 2001, 'The relationship of internal and external commitment foci to objective job performance measures', Academy of Management Journal, 44 (3), 570-580.

Sillince, John A.A.

1999a, 'The organizational setting, use and institutionalization of argumentation repertoires', Journal of Management Studies, 36, (6), 795-831.

Sillince, John A.A.

1999b, 'The role of political language forms and language coherence in the organizational change process', Organization Studies, 20 (3), 485-518.

Sillince John.A.A., Harindranath G., and Harvey Charles.E., 2001, 'Getting acceptance that radically new working practices are required: institutionalisation of arguments about change within a healthcare organisation', Human Relations, 54 (11), (November) $1421-1454$.

Sillince John.A.A, 
2002, 'A model of the strength and appropriateness of argumentation and rhetoric in organizational contexts', Journal of Management Studies, 39 (5), 585-618.

Sillince John.A.A.,

2005, 'A contingency theory of rhetorical congruence', Academy of Management Review, 30 (3), 608-621.

Slaughter, Sheila. \& Leslie, L.

1999. Academic Capitalism, Politics, Policies, and the Entrepreneurial University. Baltimore, Md: Johns Hopkins University Press.

Strauss, Anselm., \& Corbin, J.

1998. Basics of qualitative research: Techniques and procedures for developing grounded theory (2nd ed.). Thousand Oaks, CA: Sage

Symon, Gillian.

2005. Exploring resistance from a rhetorical perspective. Organization Studies. 26 (11): 1641-1664.

Van Maanen, John.

1979. The fact of fiction in organizational ethnography. Administrative Science Quarterly, 24, 53950.

Vatz, Richard.E.

1999. The myth of the rhetorical situation. 228-231 in Lucaites, John.L., Condit, Celeste.M. and Caudill, Sally. Contemporary rhetorical theory: a reader. New York. Guilford Press.

Weber, Max.

1947. The theory of social and economic organization. T. Parsons (Ed.). Glencoe, IL: Free Press. 
Jarzabkowski, P. \& J. A. A. Sillince 2007. 'A rhetoric-in-context approach to shaping commitment to multiple strategic goals'. Organization Studies, 28.10: 1639-65.

Weick Karl. E.,

1979, The social psychology of organizing, Addison-Wesley, Reading. MA. 
Appendix A: Data Sources (Precise names and descriptions avoided to preserve anonymity

\begin{tabular}{|c|c|c|c|}
\hline Data Source & Entrepreneurial & Collegiate & Modern \\
\hline $\begin{array}{l}\text { Interviews: Open- } \\
\text { ended, audio taped, } \\
\text { transcribed. }\end{array}$ & $\begin{array}{c}20 \text { interviews @ } 90 \text { minutes } \\
\text { each. }\end{array}$ & 18 interviews @ 90 minutes each. & 11 interviews @ 90 minutes each. \\
\hline $\begin{array}{l}\text { Non-participant } \\
\text { meeting observations: } \\
\text { Detailed field notes } \\
\text { taken and written up in } \\
24 \text { hours. }\end{array}$ & $\begin{array}{c}\text { Main strategy committee: } 7 \\
\text { Main income generation group: } 6 \\
\text { Main academic resourcing } \\
\text { committee: } 5 \\
\text { Other working party for actioning } \\
\quad \text { a strategic issue: } 1\end{array}$ & $\begin{array}{c}\text { Main academic resourcing } \\
\text { committee: } 7 \\
\text { Delegated governing committee: } 2 \\
\text { Academic governance committee: } 1 \\
\text { Strategic meetings with heads of } \\
\text { departments: } 1 \\
\text { Other administrative and collegial } \\
\text { committees: } 6\end{array}$ & $\begin{array}{c}\text { Main top managers meeting forum: } 3 \\
\text { Governing committee: } 2 \\
\text { Strategic meetings with heads of } \\
\text { departments: } 2 \\
\text { Academic governance committee: } 1 \\
\text { Other meetings used by TMT for } \\
\text { consultative purposes: } 6 \\
\text { Strategy day between TMT and Board: } \\
1\end{array}$ \\
\hline $\begin{array}{l}\text { Other non-participant } \\
\text { observation: Detailed } \\
\text { field notes as above. }\end{array}$ & $\begin{array}{c}1 \text { week shadowing TMT } 1 \\
\text { Pre- and post-meeting } \\
\text { observation } \\
\text { General on-site data, particularly } \\
\text { informal discussion whenever the } \\
\text { opportunity arose }\end{array}$ & $\begin{array}{l}\text { Pre- and post-meeting observation } \\
\text { General on-site data where I sat in } \\
\text { the Planning Office, next to the } \\
\text { general coffee machine; handy for } \\
\text { informal discussion }\end{array}$ & $\begin{array}{l}1 \text { week shadowing TMT } 1 \\
\text { Pre- and post-meeting observation } \\
\text { General on-site data, mostly informal } \\
\text { chats pre and post-meetings }\end{array}$ \\
\hline $\begin{array}{l}\text { Documents: Searched } \\
\text { twice, with field notes } \\
\text { taken for coding. } 1^{\text {st }} \\
\text { search to construct } \\
\text { strategic activity profile } \\
\text { and inform interview } \\
\text { questions. } 2^{\text {nd }} \text { used to } \\
\text { validate interviews and } \\
\text { antecedents of current } \\
\text { observations. }\end{array}$ & $\begin{array}{c}\text { Minutes of main strategy } \\
\text { committee, } 1992 \text { to } 1997 \\
\text { Minutes of all } 1998 \text { meetings } \\
\text { attended } \\
\text { Annual reports; Audit documents; } \\
\text { Strategic plans; Academic } \\
\text { databases; University calendars; } \\
\text { Briefing papers; Memoranda and } \\
\text { minutes of major } 1994 \text { strategic } \\
\text { initiative; Sectoral documents. }\end{array}$ & $\begin{array}{l}\text { Minutes of academic resourcing } \\
\text { committee and academic } \\
\text { governance committee, } 1992 \text { to } \\
1997 \\
\text { Minutes of delegated governing } \\
\text { committee and planning meetings, } \\
1997 \text { to } 1998 \\
\text { Minutes of all } 1998 \text { meetings } \\
\text { attended } \\
\text { Audit documents; Strategic plans; } \\
\text { University calendars; Briefing } \\
\text { papers; Handbook for Department } \\
\text { Heads; Sectoral documents. }\end{array}$ & $\begin{array}{c}\text { Planning cycle documentation since } \\
\text { inception in 1995/96 through to 1998/99 } \\
\text { Major strategic issue reports and } \\
\text { summaries from } 1993 \\
\text { Coopers and Lybrand strategy } \\
\text { consultation report, } 1988 \\
\text { Minutes of all } 1998 \text { meetings attended } \\
\text { and minutes of } 1998 \text { strategic-planning } \\
\text { TMT Meetings, not attended } \\
\text { Supporting planning documentation; } \\
\text { Annual reports and accounts; Sectoral } \\
\text { documents. }\end{array}$ \\
\hline
\end{tabular}




\section{Appendix B: List of interview participants}

\begin{tabular}{|l|l|l|}
\hline \multicolumn{1}{|c|}{ Entrepreneurial } & \multicolumn{1}{|c|}{ Collegiate } & \multicolumn{1}{c|}{ Modern } \\
\hline E1: VC x 2 & C1: VC & M1: VC \\
E2: Senior DVC x 2 & C2: DVC (Internal Affairs) & M2: Senior DVC x 2 \\
E3: DVC (Research) & C3: DVC (External Affairs) x & M3: DVC (Finance and \\
E4: DVC (Academic) & 2 & Marketing) \\
E5: Former Senior DVC x 2 & C4: Registrar x 2 & M4: DVC (Corporate \\
E6: Former DVC (Academic) & C5: Deputy Registrar & Services) \\
E7: Registrar x 2 & (Planning) & M5: DVC (Academic Affairs) \\
E8: Deputy Registrar (Academic) & C6: Deputy Registrar & x 2 \\
E9: Deputy Registrar (Finance) x & (Finance) & M6: DVC (Research and \\
2 & C7: Deputy Registrar & Consultancy) \\
E10: Deputy Registrar & (Academic) & M7: Former VC \\
(Commerce) & C8: Deputy Registrar & M8: Former Senior DVC \\
E11: Deputy Registrar (Quality) & C9: Executive Assistant to VC & M9: Deputy Registrar \\
E12: Deputy Registrar (Research) & C10: Senior Academic (1) & (Planning) \\
E13: Governor (1) & C11: Senior Academic (2) & \\
E14: Governor (2) & C12: Senior Academic (3) & \\
E15: Senior Academic & C13: Senior Academic (4) & \\
& C14: Senior Academic (5) & \\
& C15: Senior Academic (6) & \\
& C16: Senior Academic (7) & \\
& \\
\hline
\end{tabular}




\section{Table 1: Rhetorical practices at Entrepreneurial}

\begin{tabular}{|c|c|c|}
\hline Au & Rec & Sy \\
\hline $\begin{array}{l}\text { - "Trend analysis has been introduced this } \\
\text { year. We've showed them trends against } \\
\text { their performance and pushed their } \\
\text { estimates up where these were too } \\
\text { conservative" (Income meeting). } \\
\text { " Analysis of departments that fell in } \\
\text { [research] grading terms, it's been very } \\
\text { centrally inspired by the VC, and the } \\
\text { Strategy committee, who said, 'we want to } \\
\text { get back up to grade } 5 . \text { We're not content } \\
\text { with grade } 4 \text { and we hate grade 3" (E9). } \\
\text { "Professors still carry quite a lot of power } \\
\text { and you don't interfere on their patch. On } \\
\text { the other hand it's a kind of myth because } \\
\text { the moment you need to interfere on the } \\
\text { patch you do" (E4). } \\
\text {-Be tougher with academics to pull in } \\
\text { more research income and get the } \\
\text { commercial income up as well" (E1 in } \\
\text { meeting). } \\
\text { "It's unlikely to be achieved by } \\
\text { democratic means" (E13 in meeting). } \\
\text { "None of these would count if the } \\
\text { departments decided to be sulky and } \\
\text { wouldn't do anything. It's all totally } \\
\text { dependent" (E5) } \\
\text { " You've got to keep the troops on side" } \\
\text { (E7) }\end{array}$ & $\begin{array}{l}\text { "Commercial income gives you } \\
\text { autonomy, flexibility, and a stronger } \\
\text { link. You're more of a stakeholder" } \\
\text { (E4) } \\
\text {-People here have cottoned onto } \\
\text { the fact that if you earn money you } \\
\text { can control how it's spent" (E14) } \\
\text { "The Arts get more than their fair } \\
\text { share. They're beggars in that } \\
\text { sense. But they have to because of } \\
\text { the funding; the opportunities to } \\
\text { make sure they work. And they have } \\
\text { performed extremely well [in } \\
\text { research]" (E5). } \\
\text { "There has been increasing } \\
\text { recognition that those activities } \\
\text { [commercial] are part of the } \\
\text { resource base of the University. I } \\
\text { think there are still academics } \\
\text { around who are not exactly } \\
\text { sympathetic to those activities but } \\
\text { they can see the financial benefits" } \\
\text { (E6) } \\
\text { "If [A Department] isn't a } 5 \text { [in the } \\
\text { next RAE], I think there are some } \\
\text { very serious questions that are } \\
\text { going to have to be asked" (E2). }\end{array}$ & $\begin{array}{l}\text { •"In this place, the self-evident fact } \\
\text { is that the academic strength of the } \\
\text { University is growing as a direct } \\
\text { result of its financial success" } \\
\text { (E14). } \\
\text { •"We're trying to support this idea } \\
\text { of an excellent University, that's } \\
\text { research led but also does well by } \\
\text { the students and produces good } \\
\text { students" (E11). } \\
\text { "The fact that the place looks } \\
\text { good, the fact that the staff-student } \\
\text { ratio is reasonable, ... a lot of that } \\
\text { rests on additional income } \\
\text { supplementing the government } \\
\text { grant" (E2) } \\
\text { "The proudest thing I think the } \\
\text { University has achieved in the last } \\
5 \text { years ... is its national rankings } \\
\text { for teaching. Now that's a heck of } \\
\text { an achievement in parallel to its } \\
\text { rankings for research" (E1). } \\
\text { "Entrepreneurial has to make sure } \\
\text { that the commercial activities } \\
\text { maintain their momentum and } \\
\text { deliver the financial returns } \\
\text { because those underpin everything } \\
\text { we do" (E2). }\end{array}$ \\
\hline
\end{tabular}


Table 2: Rhetorical practices at Collegiate

\begin{tabular}{|c|c|c|}
\hline $\begin{array}{c}\text { Top managers construct themselves } \\
\text { Powerless rhetoric }\end{array}$ & $\begin{array}{l}\text { Position commitment to audience } \\
\text { Covert control rhetoric }\end{array}$ & $\begin{array}{l}\text { Construct multiple goal context } \\
\text { Synergy rhetoric }\end{array}$ \\
\hline $\begin{array}{l}\text { •"There are very few things you can } \\
\text { actually say that of in this place, that } \\
\text { somebody's responsible" (C7) } \\
\text { •"Collegiate doesn't have a very } \\
\text { directive process ... It would be very } \\
\text { difficult to do here anyway. I mean } \\
\text { people at Collegiate wouldn't take } \\
\text { very kindly to that. They didn't come } \\
\text { to Collegiate to be treated like that" } \\
\text { (C12). } \\
\text { •"There is a hands-off feeling to } \\
\text { research" (C13). } \\
\text { •"Collegiality insists that sudden } \\
\text { change should be resisted" (C7) } \\
\text { •"Collegiate has never wanted to } \\
\text { have a very strong hierarchy of } \\
\text { being told what to do" (C2). } \\
\text { • 'You won't get people here singing } \\
\text { the 'company song' ... They'll } \\
\text { disagree with you for the hell of it" } \\
\text { (Planning meeting). } \\
\text { •"VC's have generally come unstuck } \\
\text { when they've tried to impose a } \\
\text { sense of direction upon the } \\
\text { institution" (C14) } \\
\text { - The committees are there to } \\
\text { marginalize power (TMT 1) }\end{array}$ & $\begin{array}{l}\text {-You don't make things happen in this } \\
\text { place by being managerial. You find } \\
\text { champions for things and you work the } \\
\text { system (C4 in TMT Meeting)" } \\
\text { " There IS more control than people } \\
\text { think. But it's not overt. We know } \\
\text { exactly who is and isn't performing. ... } \\
\text { But we don't want a climate of fear. It } \\
\text { must be supporting" (C4) } \\
\text { "These people here [the TMT] run the } \\
\text { place. And we get other people to } \\
\text { think that they want what we want" } \\
\text { (VC in TMT meeting). } \\
\text { "One has the opportunities to } \\
\text { command resources but you } \\
\text { command those resources only in a } \\
\text { way that you persuade people" (C2). } \\
\text { "You do it by explaining the enormity } \\
\text { of the thing and its significance; this is } \\
\text { something which their individual staff } \\
\text { are exposed to and they are } \\
\text { responsible for" (C7). } \\
\text { "There is really relatively few areas } \\
\text { that the VC can get his way other than } \\
\text { by persuasion" (C10). } \\
\text { "The role of the [committee] is to do } \\
\text { what we want to do. It does what we } \\
\text { want " (VC in TMT meeting) }\end{array}$ & $\begin{array}{l}\text { "If you can move from a } 4 \text { to a } 5 \text { [in } \\
\text { research], it takes a lot of the income } \\
\text { pressure off in terms of generating } \\
\text { income through students, so it is an } \\
\text { attempt to try and do both" (C2). } \\
\text { " "Teaching is much more important but } \\
\text { still you couldn't get promotion on } \\
\text { teaching alone. The main criterion is } \\
\text { still the quality of one's research" (C11) } \\
\text { "Income generation is on the rise as } \\
\text { the academics begin to understand it. } \\
\text { You have to make sure they see how it } \\
\text { is not at variance with the core } \\
\text { business [research]" (C4). } \\
\text {-This is then linked to the incentive, } \\
\text { research time... more income/student } \\
\text { helps to pay for research time." } \\
\text { (Meeting) } \\
\text { "We have to find ways in which they } \\
\text { see this [commercial income] as in their } \\
\text { interests without compromising this } \\
\text { academic integrity" (C14). } \\
\text { - The University has always said it didn't } \\
\text { want commercial activities but the idea } \\
\text { some months ago was to say, well, } \\
\text { what we should do is to re-badge some } \\
\text { of the programs that we already offer } \\
\text { (C6). }\end{array}$ \\
\hline
\end{tabular}




\section{Table 3: Rhetorical practices at Modern}

\begin{tabular}{|c|c|c|}
\hline $\begin{array}{l}\text { Managers construct themselves } \\
\text { Powerless-to-change rhetoric }\end{array}$ & $\begin{array}{l}\text { Position commitment to audience } \\
\text { Directive rhetoric }\end{array}$ & $\begin{array}{l}\text { Construct multiple goal context } \\
\text { Ambivalent synergy rhetoric }\end{array}$ \\
\hline $\begin{array}{l}\text { "It is fine to talk about } \\
\text { assessment, but you actually get } \\
\text { people to try and think concretely } \\
\text { about how we are going to } \\
\text { reduce assessment load and } \\
\text { there are a million reasons why it } \\
\text { has to be exactly as it is at the } \\
\text { moment" (M5) } \\
\text { " We can have the business } \\
\text { development ideas. Getting the } \\
\text { dep'ts on board to actually do it } \\
\text { is entirely another matter" } \\
\text { (Meeting) } \\
\text {-Unless research pays, you're } \\
\text { not going to get some } \\
\text { departments giving it enough } \\
\text { attention" (M6). } \\
\text {-It's a tough area in this } \\
\text { University to get more people } \\
\text { doing research (M6) } \\
\text { "There is very much a 'them } \\
\text { and us' culture here" (VC) } \\
\text { "There are some } \\
\text { backwoodsmen and women in } \\
\text { every dep't' (M6) } \\
\text { "It is not hungry. It has never } \\
\text { been hungry" (M5) } \\
\text { "Academics don't believe in the } \\
\text { market" (M4) } \\
\text { "They can't see why they should } \\
\text { do these virtual learning and } \\
\text { business activities" (Meeting). }\end{array}$ & $\begin{array}{l}\text { "Centralising more direction and decision; } \\
\text { we're saying, 'Okay, research is something } \\
\text { that we want the University to do. Therefore, } \\
\text { Departments, we want you to address } \\
\text { research" (VC). } \\
\text { "The } 13 \text { indicators drawn up emphasize } \\
\text { those key indicators which [the top team] } \\
\text { currently consider the most important for } \\
\text { benchmarking performance" (Minutes). } \\
\text { " We're currently talking to all the academic } \\
\text { departments about their strategic plan and } \\
\text { what they envisage in terms of international } \\
\text { recruitment. I mean, we say to them, we } \\
\text { want to double numbers" (M4). } \\
\text { "On research we are going to have to } \\
\text { provide much more central leadership and } \\
\text { direction and push and be more directive" } \\
\text { (VC). } \\
\text {-We're keeping a very close check on what } \\
\text { they're doing in terms of publication, what } \\
\text { they're doing in terms of income, what they're } \\
\text { doing in terms of PhD students because } \\
\text { those are the things that count in the RAE. } \\
\text { We're monitoring this closely (M6) } \\
\text { - There are ways that the University wants to } \\
\text { travel and we're going to look fairly carefully } \\
\text { at what you're doing to make sure that you're } \\
\text { going in that direction (VC). } \\
\text { "We expect departments to double or treble } \\
\text { the money they get for the University so } \\
\text { we're setting gearing ratios in there and we'll } \\
\text { be monitoring all this" (M6) }\end{array}$ & $\begin{array}{l}\text { •"The main concern that staff have } \\
\text { about doing more research is not } \\
\text { having enough time to do it. We're } \\
\text { trying to thin out teaching because } \\
\text { we do over teach" (M6) } \\
\text {-Modern has got a good and } \\
\text { developing reputation but it's not } \\
\text { going to maintain that unless it } \\
\text { underpins it with research ... good } \\
\text { universities have strong research } \\
\text { profiles ... It underpins teaching, it } \\
\text { gives you a national and international } \\
\text { reputation. It brings in resources (M6) } \\
\text {-If you invest resources and time } \\
\text { linto research] you actually detract } \\
\text { from the amount of resources and } \\
\text { time you're putting into the students } \\
\text { and the learning and teaching. What } \\
\text { we should be doing is consultancy ... } \\
\text { we make good profit out of doing } \\
\text { consultancy (M3) } \\
\text { "There is a real contradiction here. } \\
\text { Research funding brings the prestige, } \\
\text { they bring the articles but they don't } \\
\text { bring the overheads for the } \\
\text { University" (M6). } \\
\text { "It doesn't know whether it wants to } \\
\text { be a teacher or a researcher or a } \\
\text { consultancy organization" (M5). } \\
\text { "What are we trying to generate, } \\
\text { research money or real money?" } \\
\text { (Meeting) }\end{array}$ \\
\hline
\end{tabular}




\section{Table 4: Cross-case comparison}

\begin{tabular}{|c|c|c|c|}
\hline & $\begin{array}{l}\text { Historical context: Degree of } \\
\text { change involved in } \\
\text { encompassing multiple goals }\end{array}$ & $\begin{array}{l}\text { Rhetorical influence: } \\
\text { Internal consistency of } \\
\text { rhetorical practices and } \\
\text { their overall influence }\end{array}$ & $\begin{array}{l}\text { Commitment: Influence } \\
\text { over commitment to } \\
\text { multiple goals }\end{array}$ \\
\hline Entrepreneurial & $\begin{array}{l}\text {-Stable overall context } \\
\text {-Multiple goals established and } \\
\text { are already being performed } \\
\text {-Change required only in some } \\
\text { departments about some goals }\end{array}$ & $\begin{array}{l}\text { 'Authority', 'reciprocity' and } \\
\text { 'synergy' rhetorics are } \\
\text { internally consistent } \\
\text {-Overall assertive rhetorical } \\
\text { influence }\end{array}$ & $\begin{array}{l}\text {-Able to influence } \\
\text { academics to widen } \\
\text { commitment to } \\
\text { encompass multiple } \\
\text { goals }\end{array}$ \\
\hline Collegiate & $\begin{array}{l}\text {-Change process underway } \\
\text {-Multiple goals established and } \\
\text { some performance of multiple } \\
\text { goals although this is not } \\
\text { organization-wide } \\
\text { - Careful approach to change due } \\
\text { to strong norms of autonomy }\end{array}$ & $\begin{array}{l}\text {-Powerless', 'covert control' } \\
\text { and 'synergy' rhetorics are } \\
\text { internally consistent } \\
\text {-Overall persuasive } \\
\text { rhetorical influence }\end{array}$ & $\begin{array}{l}\text {-Able to influence } \\
\text { academics to widen } \\
\text { commitment to } \\
\text { encompass multiple } \\
\text { goals }\end{array}$ \\
\hline Modern & $\begin{array}{l}\text {-Early phase of major } \\
\text { organizational change } \\
\text {-Multiple goals not established } \\
\text { and still not clear to top managers } \\
\text {-Whole organization change } \\
\text { needed, as there is no } \\
\text { organization-wide commitment to } \\
\text { multiple goals }\end{array}$ & $\begin{array}{l}\text {-Powerless-to-change', } \\
\text { 'directive' and 'ambivalent } \\
\text { synergy' rhetorics are } \\
\text { internally inconsistent } \\
\text { •Overall contradictory } \\
\text { rhetorical influence }\end{array}$ & $\begin{array}{l}\text {-Academics perceive } \\
\text { commitment to multiple } \\
\text { goals as a zero-sum } \\
\text { game, in which } \\
\text { commitment to some } \\
\text { goals means sacrificing } \\
\text { other goals }\end{array}$ \\
\hline
\end{tabular}

